\title{
The Effect of Long-Term Pulsing Electromagnetic Field Stimulation on Experimental Osteoporosis of Rats
}

\author{
Shinichi MISHIMA \\ Department of Orthopedic Surgery, School of Medicine, University of Occupational and \\ Environmental Health, Japan. Kitakyushu 807, Japan
}

Abstract: The author performed experiments in order to investigate what biological effect on the bone would be produced by long-term pulsing electromagnetic field (PEMF) systemic stimulation. In some of the mature female rats used as experimental animals, bilateral ovariectomy and right sciatic neurectomy were performed in order to make a model of osteoporosis. PEMF stimulation was produced by repetitive pulse burst (RPB) waves at a positive amplitude of $25 \mathrm{mV}$, negative amplitude of $62.5 \mathrm{mV}$, burst width of $4.2 \mathrm{~ms}$, pulse width of $230 \mu \mathrm{s}$ and $12 \mathrm{~Hz}$, with the magnetic field strength within a cage being set at 3-10 Gauss. PEMF stimulation over 6 months did not produce any effects on the physiologically aged bones. PEMF stimulation also did not produce any effects on losed cortical bone in osteoporotic hindlegs. On the other hand, an increase of bone volume and bone formation activity was observed in the cancellous bone of osteoporotic hindlegs. These findings suggested that PEMF stimulation exerted a preventive effect against bone loss of osteoporotic hindlegs. Furthermore, an observed increase in bone marrow blood flow seemed to be related with this increase of bone volume and bone formation activity.

Key words : rat, osteoporosis, pulsing electromagnetic fields, bone marrow blood flow.

(Received 16 November 1987)

\section{Introduction}

Recent attention has been paid to the phenomenon that bone formation may be promoted by micro-electrical current stimulation. In 1953, Yasuda (1984) expanded his biodynamic research relating to callus formation and demonstrated that bending of the long tubular bone was associated with development of electrical current. He called this "piezoelectric phenomenon". Furthermore, by passing direct micro-electrical current through the rabbit femoral bone, he found a large amount of callus at the negative pole, and he called this "electrical callus" because it was generated by electrical current. In 1955, Yasuda et al. (1984) reported first the clinical applications of the phenomenon to the treatment of fresh fracture, delayed union, pseudoarthrosis, Perthes disease and bone cyst. Later in and after the 1960s, Bassett (1962), Bassett \& Pawluk (1964), Friedenberg \& Brighton (1966), Friedenberg et al. (1970, 1974), Brighton \& Heppenstall (1971) and Krauss \& Lechner (1972) published their experimental and clinical reports on promotion of bone union by micro-electrical current. 
Electrical stimulation is produced by various methods, such as direct current, pulse wave, alternating current, electrolet teflon membrane and pulsing electromagnetic fields (PEMF). Unlike direct stimulation, PEMF stimulation is noninvasive and can provide uniform magnetic fields over a relatively extensive area. Therefore, this can be more easily applied to living bodies. The biological effect of PEMF stimulation on the bone has been reported as to not only the promotion of bone union of fractures but also the promotion of bone union in congenital pseudoarthroses (Bassett et al., 1981; Sutcliffe \& Goldberg, 1982) and improvement of blood flow in avascular necroses (Rinsky et al., 1980). However, the mechanism of the biological effect on the bone has not yet been fully clarified.

The purpose of this study is to investigate whether long-term PEMF stimulations are able to prevent bone loss due to pathological osteoporotic conditions.

\section{Materials and Methods}

1. Material

A total of 94,8 months Wister female rats (multiparous $\mathrm{IV}$, weighing about $200-250$ g) was studied. Of these animals, 64 received a pre-treatment of bilateral ovariectomy and right sciatic neurectomy, and were called the operated group. Of this group, some rats began to receive PEMF stimulation 3 months after the pre-treatment lasting over a period of 6 months. Depending on experimental conditions, 94 rats were divided into 4 groups of unoperated/unstimulated (control), unoperated/stimulated $(\mathrm{u} / \mathrm{s})$, operated/unstimulated $(\mathrm{o} / \mathrm{u})$ and operated/stimulated $(\mathrm{o} / \mathrm{s})$. These rats were sacrificed at 3,6 and 9 months after the beginning of the experiment as shown in Table 1.

2. Cage and generator of PEMF stimulation

Both the cage and the generator of PEMF stimulation were made in this department. Cages, each measuring $28 \times 38 \times 16 \mathrm{~cm}$, were piled up in 4 layers, and 2 or 3 rats were fed in each cage and allowed free access to Nihon Clea's pellets (CE-2) and tap water. Rats of the stimulated group were placed in the piled-up cages the outside of which was coiled around with Holmar's copper wires $(0.80 \mathrm{~mm}$ diameter $)$. These wires were connected to the generator of PEMF. Repetitive pulse burst (RPB) with a burst width of 4.2 $\mathrm{ms}$, pulse width of $230 \mu \mathrm{s}$ and $12 \mathrm{~Hz}$ was passed through this coil from the generator of PEMF and the magnetic field strength within these cages was set at 3-10 Gauss (Fig. 1).

Table 1. Glassification of experimental conditions of rats

\begin{tabular}{lcccc}
\hline & \multicolumn{4}{c}{ No. of rats sacrificed } \\
\cline { 2 - 5 } Group & 3 months & 6 months & 9 months & Total \\
\hline Unoperated/unstimulated (control) & 6 & 5 & 9 & 20 \\
Unoperated/stimulated & & & 10 & 10 \\
Operated/unstimulated & 9 & 11 & 15 & 35 \\
Operated/stimulated & & 12 & 17 & 29 \\
\hline \multicolumn{1}{c}{ Total } & 15 & 28 & 51 & 94 \\
\hline
\end{tabular}



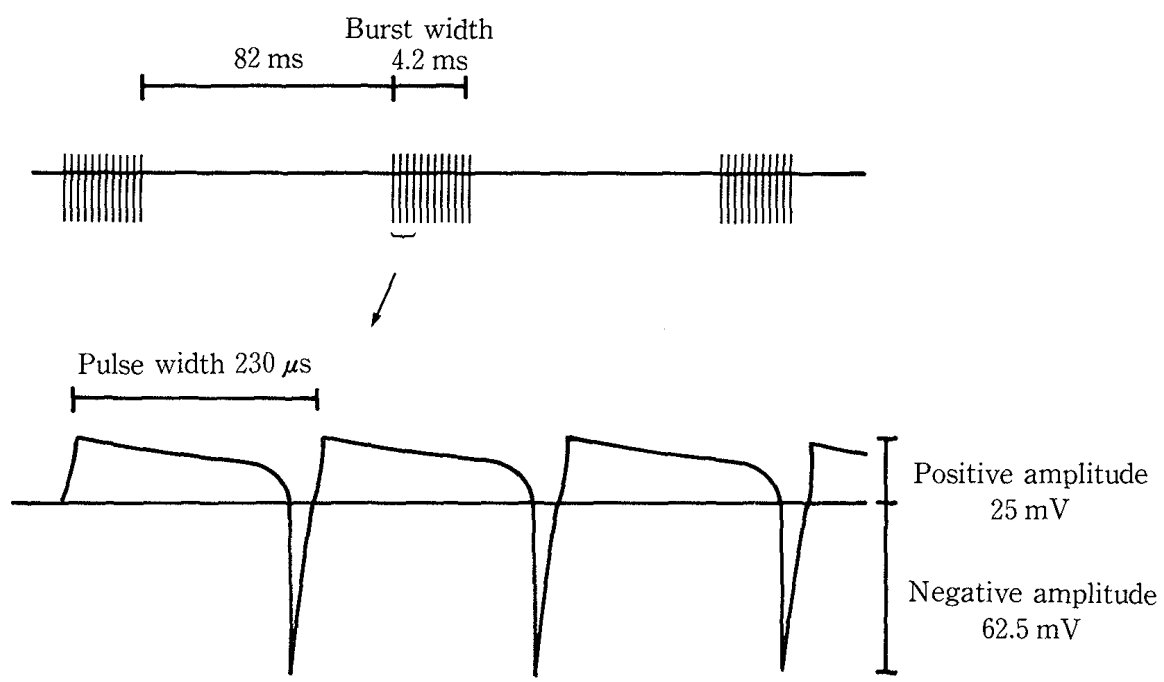

Fig. 1. Diagram showing the outline of $12 \mathrm{~Hz}$ repetitive pulse burst (RPB). The magnetic field strength within the cage reached 3 Gauss at the central part and 10 Gauss at the marginal part.

3. Item of observation

For reference, body weights were measured every month, and serum-Ca, -P and -ALP levels were measured by an autoanalyzer (Olympus' improved model of ACA 8000) at the time of sacrifice.

a) Soft X-ray observation

After complete removal of soft tissues, the right femur was put on an alminium plate $(2$ $\mathrm{mm}$ thick) and irradiated together with the alminium slope wedge at exposure conditions of $5 \mathrm{~mA}, 34 \mathrm{KVp}$ and $60 \mathrm{~min}$ and at a distance of $45 \mathrm{~cm}$. The length of the femur was measured by a slide caliper and then the indices were calculated at the central part of the femur by the microdensitometry (MD) method (Inoue et al., 1980, 1981).

b) Measurement of the bone strength

Using the stretching/compressing tester (Shimadzu's Autograph S model), strength of the right tibia was tested under the bending load. The tibia was placed on a supporting table $(2.0 \mathrm{~cm}$ span) in such a way that its middle part was loaded from the medial to the lateral side, and the loading to the rupture was measured by delineating the load-time curve under the condition of a full-scale weight of $10 \mathrm{~kg}$, cross head speed of $5 \mathrm{~mm} / \mathrm{min}$ and chart speed of 40 $\mathrm{mm} / \mathrm{min}$.

c) Measurement of bone marrow blood flow

Using a UH meter PHG-201 (Unique Medical), which contained the hydrogen clearance system, bone marrow blood flow was measured at the diaphysis of the right femur. Under the anesthesia, a $0.4 \mathrm{~mm}$ diameter hole was drilled at the diaphysis, and a platinum electrode of $0.3 \mathrm{~mm}$ diameter was inserted into bone marrow quickly as a barrier electrode and fixed in the hole. Plate-type silver chloride electrodes as non-barrier electrodes were embedded under the skin of the thigh. When the respiratory conditions of these rats were stabilized at $70-90 / \mathrm{min}$, they were allowed to inhale hydrogen together with room air, and these clearance 
curves were measured. Blood flows were calculated according to the method of Aukland et al. (1964) and Whiteside et al. (1977a).

d) Light-microscopic observation

Using the Yoshiki (1983) method with H. E. staining which was retreated with cyanuric chloride during fixation, decalcified samples were prepared from the cross section of the right femur at its middle part and the sagittal section of this bone at its distal metaphysis. Furthermore, undecalcified samples of the same parts were also prepared according to the method of Konno \& Takahashi (1983), and some of them were examined by Villaneuva bone staining, while others by Villaneuva Goldner staining. Bone histomorphometry by Cosmozone 98 (Nikon), the system for picture analysis, was also used on these decalcified samples. Parameters used were those proposed by Takahashi (1983).

\section{Results}

All groups showed weight increases with time, which was more prominent in the operated groups than in the unoperated ones. PEMF stimulation did not have any influences on body weight (Fig. 2). No specific changes were observed for serum-Ca, -P and -ALP levels (Table 2).

Macroscopic examination of soft X-ray pictures of the right femur in the operated groups revealed osteoporotic changes in the cancellous bone together with thinning of the cortical bone width as early as 3 months. After that, those changes did not show any

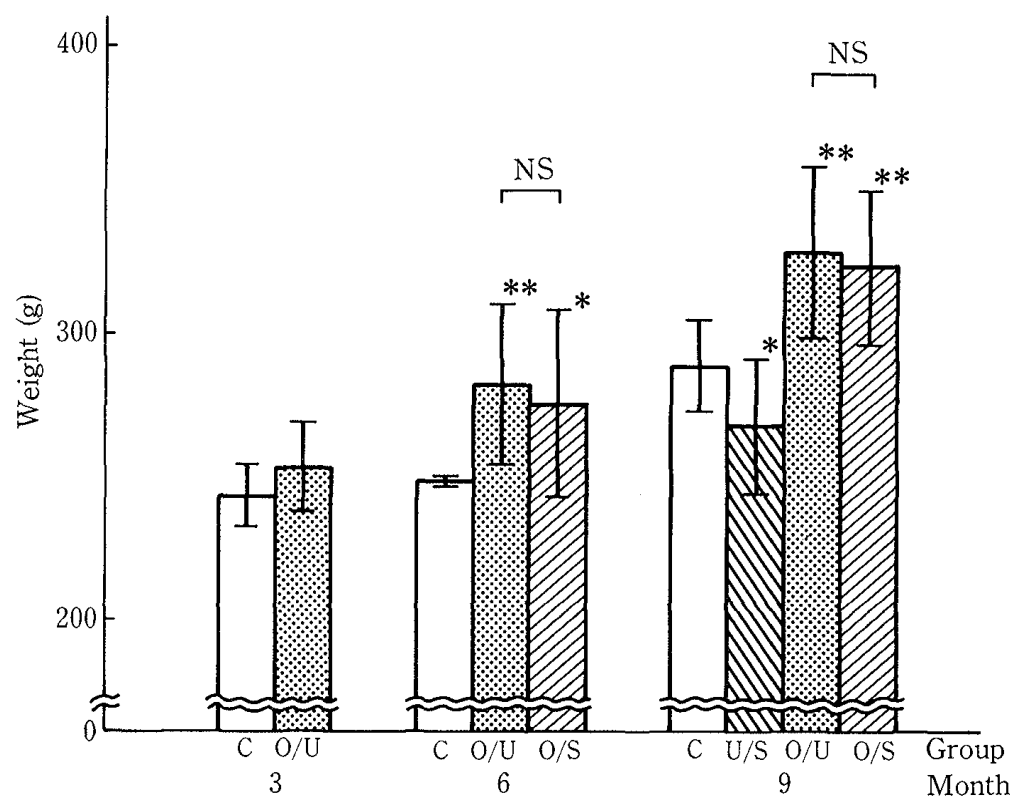

Fig. 2. Changes in body weight.

C : Unoperated/unstimulated (Control) group

U/S : Unoperated/stimulated group

$\mathrm{O} / \mathrm{U}:$ Operated/unstimulated group

$\mathrm{O} / \mathrm{S}:$ Operated/stimulated group

${ }^{*} P<0.05 \quad{ }^{* *} P<0.01$ (t-test vs. control group) 
Table 2. Biochemical findings of serum samples

\begin{tabular}{|c|c|c|c|c|c|c|c|c|c|}
\hline \multirow{2}{*}{\multicolumn{2}{|c|}{ Group }} & \multirow[b]{2}{*}{ Month } & \multirow[b]{2}{*}{$\mathrm{N}$} & \multicolumn{2}{|c|}{$\mathrm{Ca}(\mathrm{mEq} / \ell)$} & \multicolumn{2}{|c|}{$\mathrm{P}(\mathrm{mg} / \mathrm{dl})$} & \multicolumn{2}{|c|}{$\operatorname{ALP}(\mathrm{U})$} \\
\hline & & & & Mean & $\mathrm{SD}$ & Mean & $\mathrm{SD}$ & Mean & $\mathrm{SD}$ \\
\hline \multirow[t]{3}{*}{ Unoperated/unstimulated } & (control) & 3 & 4 & 5.6 & 0.9 & 6.1 & 2.0 & 27.5 & 8.6 \\
\hline & & 6 & 4 & 5.2 & 0.2 & 3.7 & 1.0 & 14.9 & 1.9 \\
\hline & & 9 & 9 & 5.1 & 0.3 & $4: 0$ & 0.9 & 18.3 & 2.0 \\
\hline Unoperated/stimulated & & 9 & 8 & 5.1 & 0.2 & 3.4 & 1.7 & 20.0 & 2.4 \\
\hline \multirow{3}{*}{\multicolumn{2}{|c|}{ Operated/unstimulated }} & 3 & 9 & 4.4 & 0.5 & 6.8 & 0.9 & 25.9 & 4.6 \\
\hline & & 6 & 9 & 4.8 & 0.5 & 5.1 & 1.4 & 23.0 & 5.7 \\
\hline & & 9 & 15 & 5.1 & 0.2 & 4.5 & 1.7 & 24.2 & 2.5 \\
\hline \multirow{2}{*}{\multicolumn{2}{|c|}{ Operated/stimulated }} & 6 & 12 & 4.3 & 0.6 & 4.5 & 1.0 & 17.1 & 5.5 \\
\hline & & 9 & 16 & 5.2 & 0.4 & 4.7 & 2.2 & 20.8 & 4.6 \\
\hline
\end{tabular}

marked progressions. There was no difference between the stimulated group and the unstimulated one (Fig. 3).

The length of the right femur slightly increased with aging, but no differences were observed among these four groups (Fig. 4).

In the operated groups, the middle part of the right femur showed an increase in $\mathrm{d}$ value and a decrease in $\mathrm{MCl}$ value by the MD method, while there were no significant differences between the stimulated groups and the unstimulated ones. $\Delta$ GSmin, $\Delta$ GSmax and $\Sigma$ GS/D values, generally accepted as indices of the bone density, were found to be significantly lower in the operated groups. However, the bone density tended to be higher in the o/s group than in the o/u one (Table 3 ).

In the 3-point bending test of the right tibia, the operated groups showed a decrease in the rupture-inducing loading volume, but showed a recovering tendency at 9 months. However, there was no significant difference between the stimulated group and the unstimulated one (Fig. 5).

The marrow blood flow in the diaphysis of the right femur was found to be significantly lower at 3 months after the beginning of the experiment in the operated group than in the unoperated one. But after that, the flow in the operated group gradually increased subsequently, especially the flow of the $\mathrm{o} / \mathrm{s}$ group showed a value considerably closer to the one of the control group at 9 months (Fig. 6).

Histologically, the cortical bone of the operated groups showed a decrease in the bone volume (Fig. 7), which was supported by the measurement of the cortical-total area ratio (Table 4). However, there were no differences between the stimulated group and the unstimulated one. In the cancellous bone, the operated groups showed thinning and decreasing of the trabecular bone with decreasing of the osteoid (Fig. 8). These were reflected in decreases of the trabecular bone specific volume (tVsp), mean trabecular thickness (MTT) and relative osteoid volume (ROV) under the histomorphometry. Furthermore, the operated groups showed a decrease in the fractional formation surface (FrFs). As to the effect of PEMF stimulation, there were no differences between the control group and the $\mathrm{u} / \mathrm{s}$ one, while all of $\mathrm{tVsp}, \mathrm{MTT}, \mathrm{ROV}$ and FrFs were found to be greater in the o/s group 
than in the o/u one (Table 4).

\section{Discussion}

The effect of electrical stimulation on the bone has been investigated mainly from the aspect of promotion of bone union. Bassett et al. (1982) reported that the clinical application of PEMF stimulation yielded good results in about $80 \%$ of the patients with 1007 ununited fractures and 71 failed arthrodeses. Furthermore, Bassett (1984) reported that in nonunions and delayed unions, the fracture gap is bridged by fibrocartilage and blocks vascular invasion for months or years until calcification has occurred. Normally, calcifica-

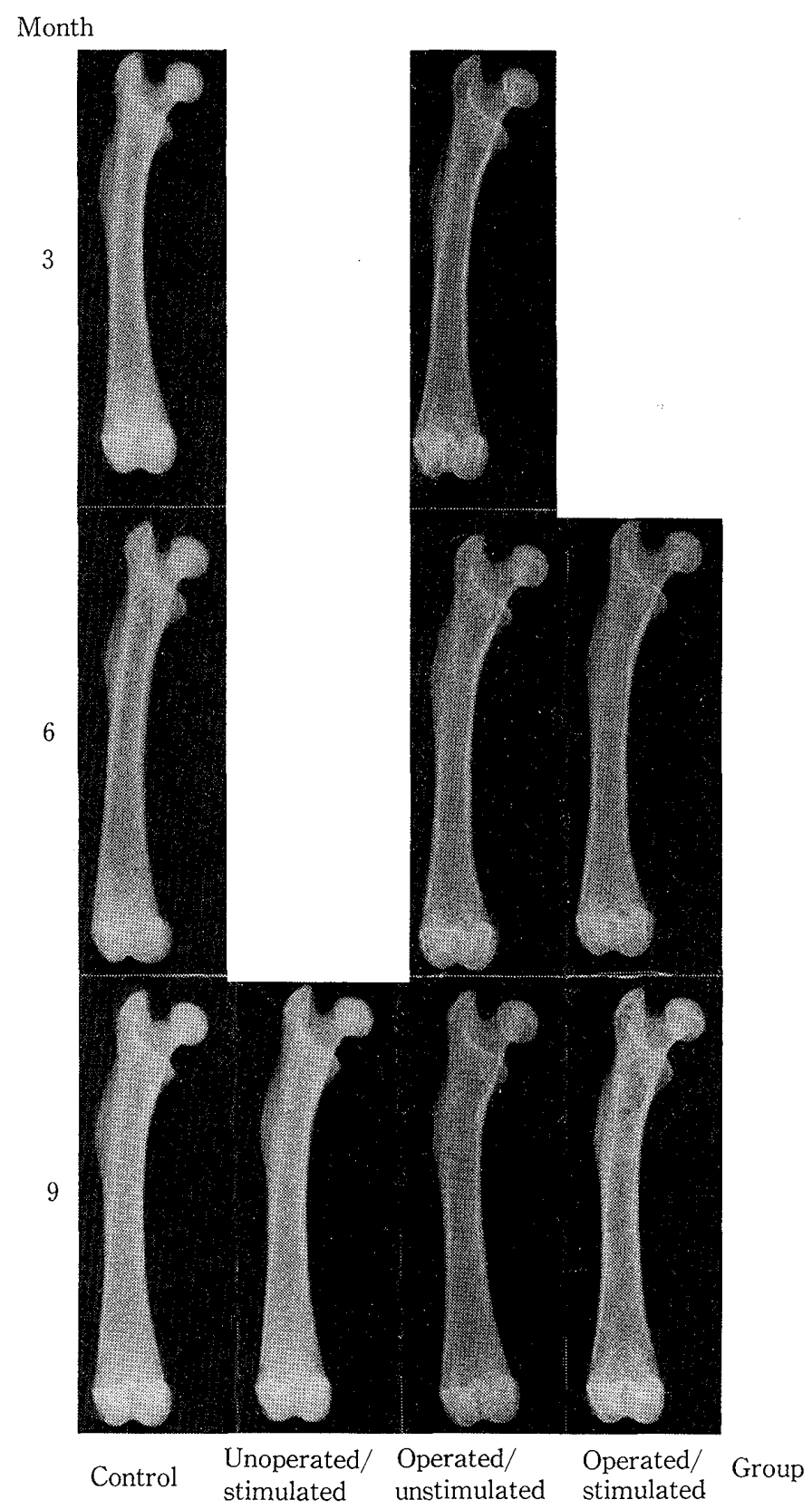

Fig. 3. Osteoporotic changes of the femur in the operated groups. 
tion of this tissue ensues, setting the stage for vascular penetration, chondroclasis, and replacement by fiber and lamellar bone. PEMF stimulation not only increases the calcium content of chondrocytes but also appears to trigger calcification of the "blocking" fibrocartilage so that the normal final phases of fracture healing can follow. However, much is still unknown about the extremely complicated meachanism of PEMF stimulated bone induction. There has also been few reports on the effect of PEMF stimulation on various conditions of bone except bone union.

The essential pathology of osteoporosis may be described as a decrease in the total mass of bone below levels needed for mechanical support (Heaney, 1965). No etiology

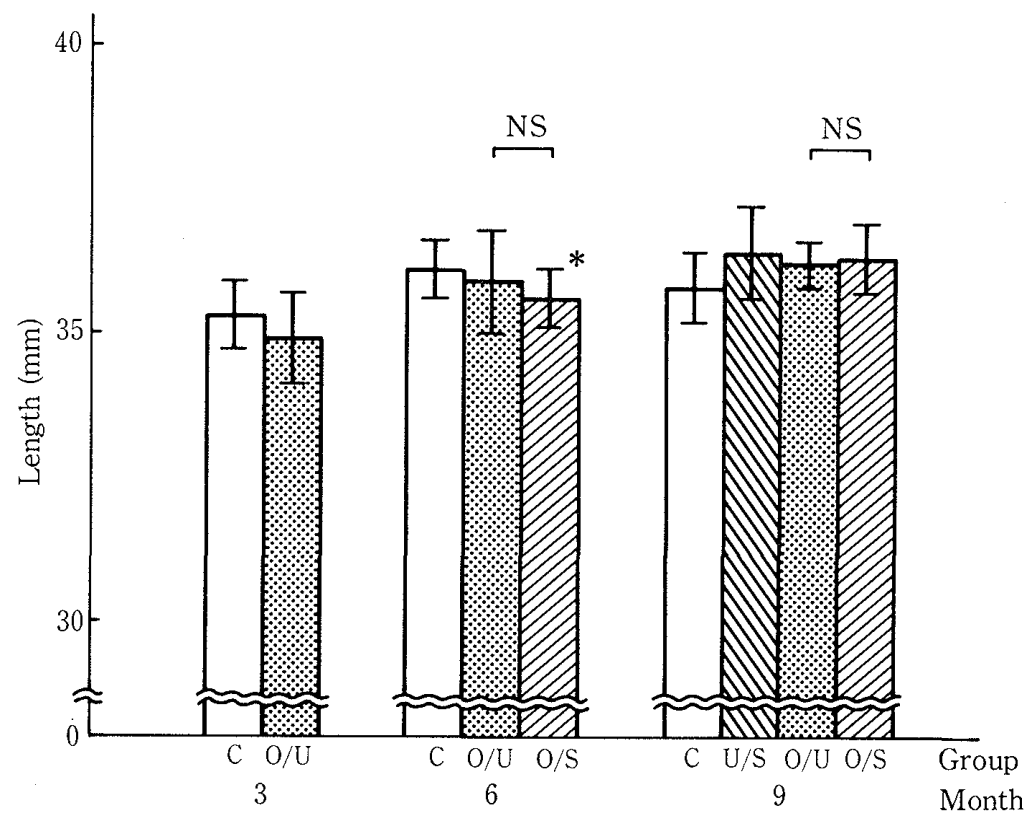

Fig. 4. Length of the right femur.

C : Unoperated/unstimulated (Control) group

U/S : Unoperated/stimulated group

$\mathrm{O} / \mathrm{U}:$ Operated/unstimulated group

$\mathrm{O} / \mathrm{S}:$ Operated/stimulated group

${ }^{*} P<0.05$ (t-test vs. control group)

Table 3. Index values at the middle part of the right femur by the microdensitometry method

\begin{tabular}{|c|c|c|c|c|c|c|c|c|c|c|c|c|c|c|}
\hline \multirow[b]{2}{*}{ Group } & \multirow[b]{2}{*}{ Month } & \multirow[b]{2}{*}{$\mathrm{N}$} & \multicolumn{2}{|c|}{$\mathrm{D}(\mathrm{mm})$} & \multicolumn{2}{|c|}{$\mathrm{d}(\mathrm{mm})$} & \multicolumn{2}{|c|}{$\mathrm{MCl}$} & \multicolumn{2}{|c|}{$\underset{(\mathrm{mmAl})}{\Delta \mathrm{GSmin}}$} & \multicolumn{2}{|c|}{$\underset{(\mathrm{mmAl})}{\Delta \mathrm{GSmax}}$} & \multicolumn{2}{|c|}{$\underset{(\mathrm{mmAl})}{\sum \mathrm{GS} / \mathrm{D}}$} \\
\hline & & & Mean & $\mathrm{SD}$ & Mean & $\mathrm{SD}$ & Mean & $\mathrm{SD}$ & Mean & $\mathrm{SD}$ & Mean & SD & Mean & $\mathrm{SD}$ \\
\hline \multirow{3}{*}{$\begin{array}{l}\text { Unoperated/unstimulated } \\
\text { (Control) }\end{array}$} & 3 & 4 & 3.13 & 0.10 & 1.89 & 0.10 & 0.394 & 0.038 & 1.22 & 0.09 & 2.05 & 0.13 & 1.35 & 0.06 \\
\hline & 6 & 2 & 3.25 & 0.02 & 1.86 & 0.02 & 0.408 & 0.004 & 1.28 & 0.04 & 2.02 & 0.01 & 1.36 & 0.05 \\
\hline & 9 & 9 & 3.19 & 0.12 & 1.93 & 0.14 & 0.395 & 0.033 & 1.27 & 0.14 & 2.11 & 0.18 & 1.41 & 0.14 \\
\hline Unoperated/stimulated & 9 & 10 & 3.18 & 0.23 & 1.93 & 0.13 & 0.391 & 0.028 & 1.31 & 0.09 & 2.03 & 0.10 & 1.41 & 0.10 \\
\hline \multirow[t]{3}{*}{ Operated/unstimulated } & 3 & 5 & 3.11 & 0.11 & 2.06 & 0.09 & 0.337 & 0.013 & 1.06 & 0.09 & 1.87 & 0.19 & 1.21 & 0.10 \\
\hline & 6 & 10 & 3.10 & 0.16 & 2.14 & 0.12 & 0.309 & 0.031 & 0.99 & 0.06 & 1.81 & 0.12 & 1.14 & 0.05 \\
\hline & 9 & 15 & 3.16 & 0.17 & 2.17 & 0.08 & 0.315 & 0.017 & 1.03 & 0.10 & 1.91 & 0.08 & 1.21 & 0.07 \\
\hline \multirow[t]{2}{*}{ Operated/stimulated } & 6 & 11 & 3.08 & 0.13 & 2.10 & 0.11 & 0.317 & 0.026 & 1.04 & 0.15 & 1.89 & 0.34 & 1.20 & 0.19 \\
\hline & 9 & 17 & 3.18 & 0.11 & 2.16 & 0.14 & 0.323 & 0.031 & 1.09 & 0.11 & 1.98 & 0.15 & 1.27 & 0.10 \\
\hline
\end{tabular}




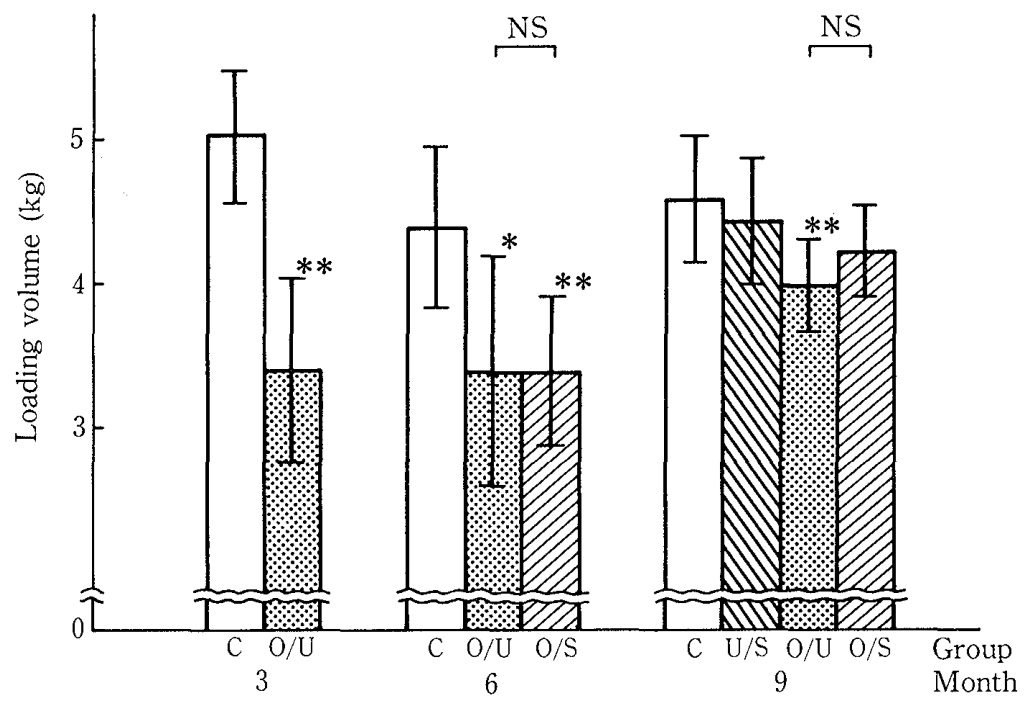

Fig. 5. Loading volume inducing rupture of the right tibia in the 3-point bending test.

C : Unoperated/unstimulated (Control) group

$\mathrm{U} / \mathrm{S}$ : Unoperated/stimulated group

$\mathrm{O} / \mathrm{U}:$ Operated/unstimulated group

$\mathrm{O} / \mathrm{S}:$ Operated/stimulated group

${ }^{*} P<0.05{ }^{* *} P<0.01$ (t-test vs. control group)

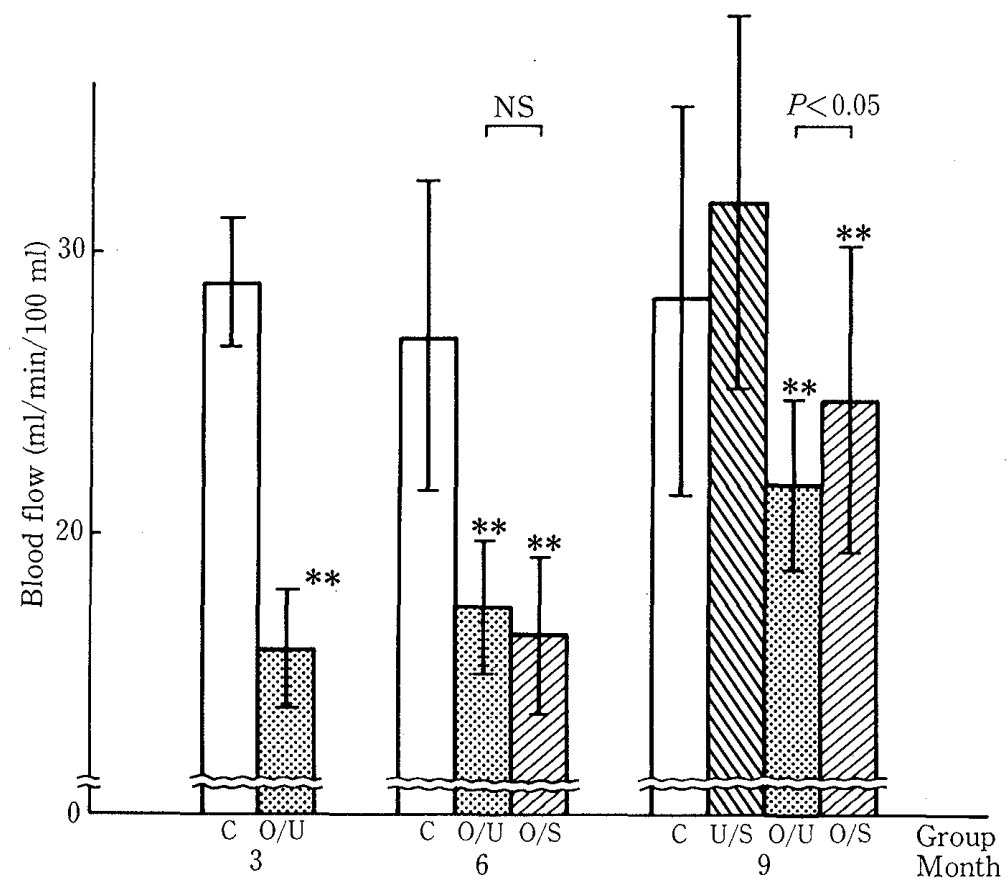

Fig. 6. Bone marrow blood flow in the right femoral diaphysis.

C : Unoperated/unstimulated (Control) group

U/S : Unoperated/stimulated group

$\mathrm{O} / \mathrm{U}:$ Operated/unstimulated group

$\mathrm{O} / \mathrm{S}:$ Operated/stimulated group

${ }^{* *} P<0.01$ (t-test vs. control group) 


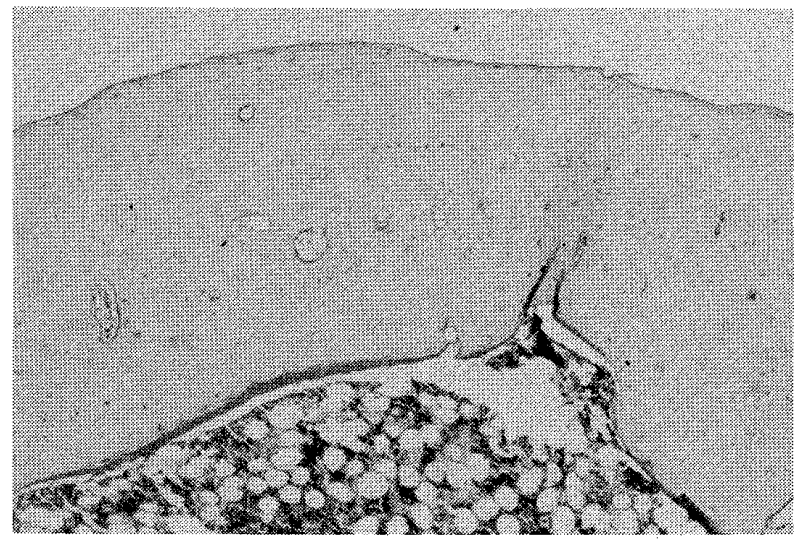

Control group

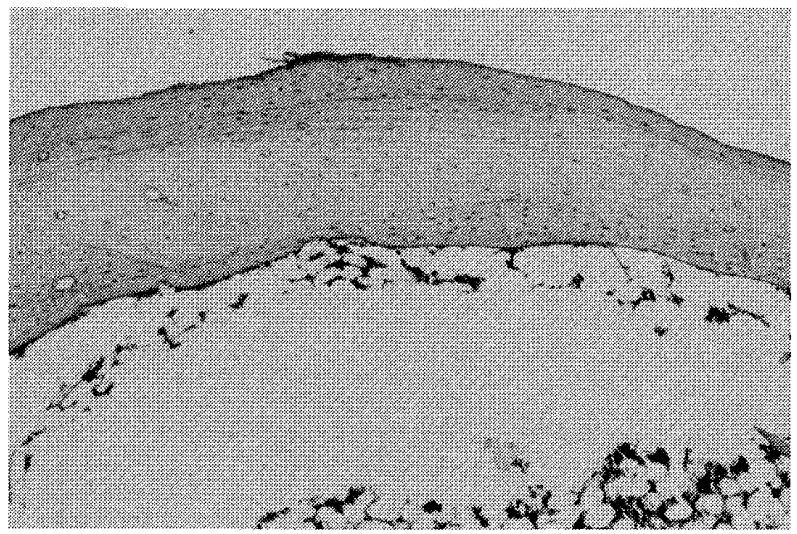

Operated/unstimulated group

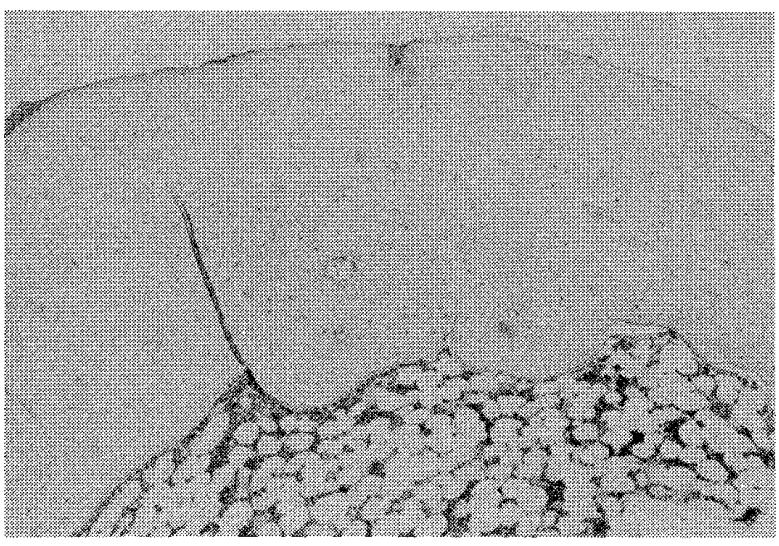

Unoperated/stimulated group

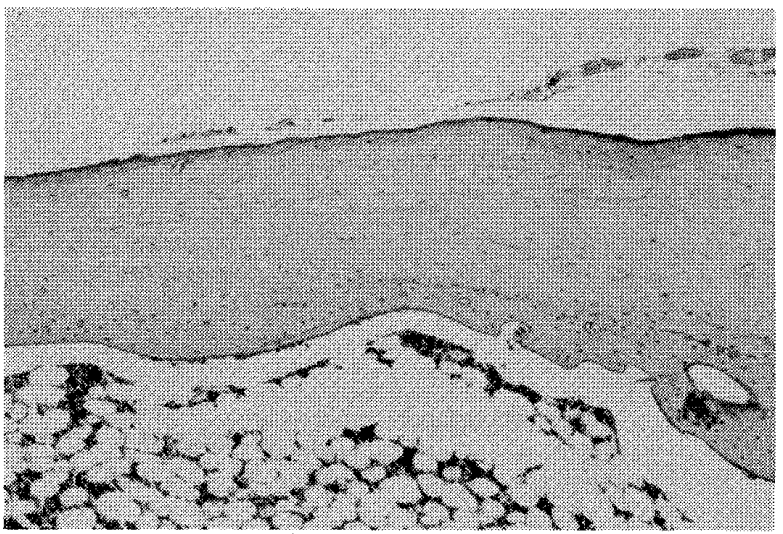

Operated/stimulated group

Fig. 7. Histological picture of the cross section of the right femur at the middle part.

9 months after the beginning of experiment.

H. E. stain retreated with cyanuric chloride during fixation.

Table 4. Bone histomorphometry at 9 month after the beginning of experiment

\begin{tabular}{|c|c|c|c|c|c|c|c|c|c|c|c|}
\hline \multirow[b]{3}{*}{ Group } & \multirow[b]{3}{*}{$\mathrm{N}$} & \multirow{2}{*}{\multicolumn{2}{|c|}{$\frac{\text { Cortical bone }}{\text { Ac/At ratio }(\%)}$}} & \multicolumn{8}{|c|}{ Cancellous bone } \\
\hline & & & & \multicolumn{2}{|c|}{$\operatorname{tVsp}(\%)$} & \multicolumn{2}{|c|}{$\operatorname{MTT}(\mu \mathrm{m})$} & \multicolumn{2}{|c|}{$\operatorname{ROV}(\%)$} & \multicolumn{2}{|c|}{$\operatorname{FrFS}(\%)$} \\
\hline & & Mean & $\mathrm{SD}$ & Mean & $\mathrm{SD}$ & Mean & $\mathrm{SD}$ & Mean & SD & Mean & SD \\
\hline $\begin{array}{l}\text { Unoperated/unstimulated } \\
\text { (Control) }\end{array}$ & 9 & 58.5 & 1.7 & 25.6 & 6.0 & 74.8 & 11.4 & 8.9 & 3.0 & 6.4 & 1.4 \\
\hline Unoperated/stimulated & 10 & 61.5 & 4.0 & 26.4 & 4.0 & 69.4 & 2.0 & 7.3 & 3.6 & 7.9 & 2.2 \\
\hline Operated/unstimulated & 15 & 51.7 & 3.2 & 7.5 & 2.3 & 53.8 & 1.9 & 3.9 & 0.6 & 5.5 & 1.0 \\
\hline Operated $/$ stimulated & 17 & 54.8 & 6.1 & 10.3 & 3.3 & 57.6 & 8.7 & 6.4 & 3.9 & 6.6 & 0.5 \\
\hline
\end{tabular}

The measurement for the cortical bone was done at the cross section of the middle part of the right femur and the measurement for the cancellous bone was done at the distal metaphysis of the right femur (sagital section).

Ac/At ratio: Cortical-total area ratio, tVsp: Trabecular bone specific volume

MTT: Mean travecular thickness, ROV: Relative osteoid volume,

FrFS: Fractional formation surface 


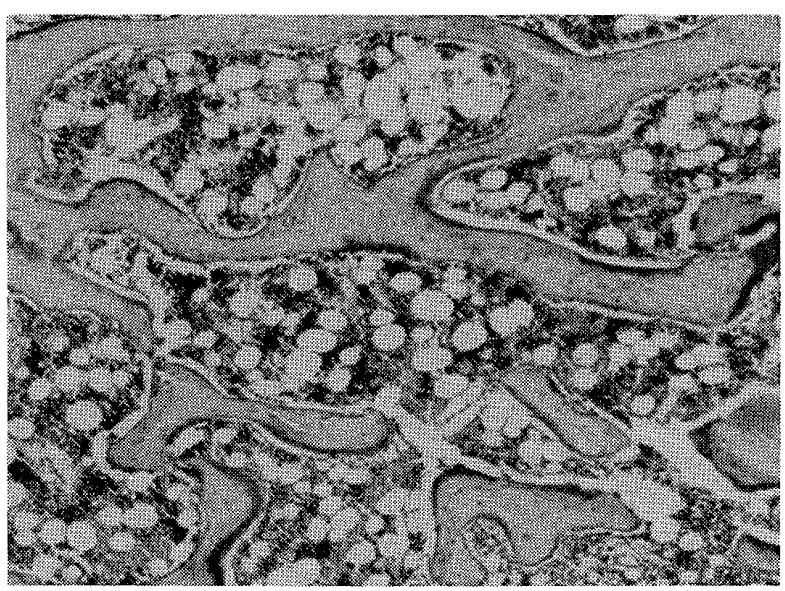

Control group

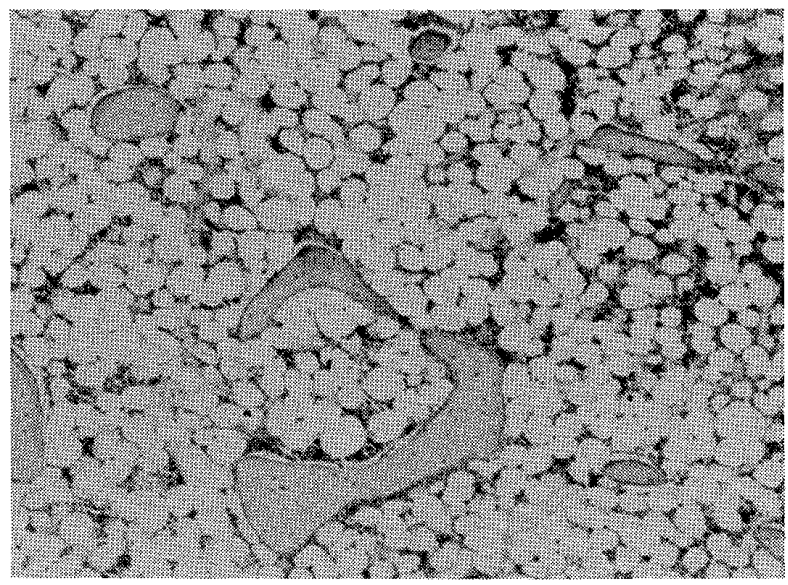

Operated/unstimulated group

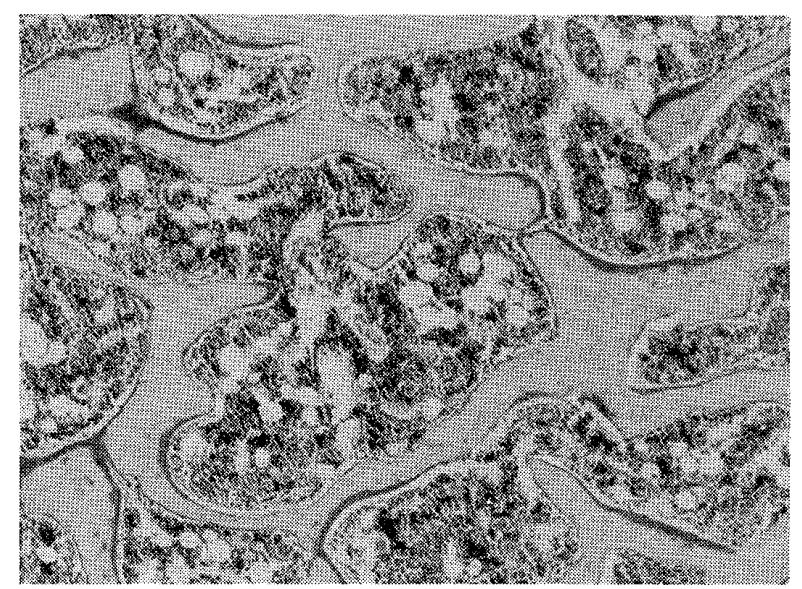

Unoperated/stimulated group

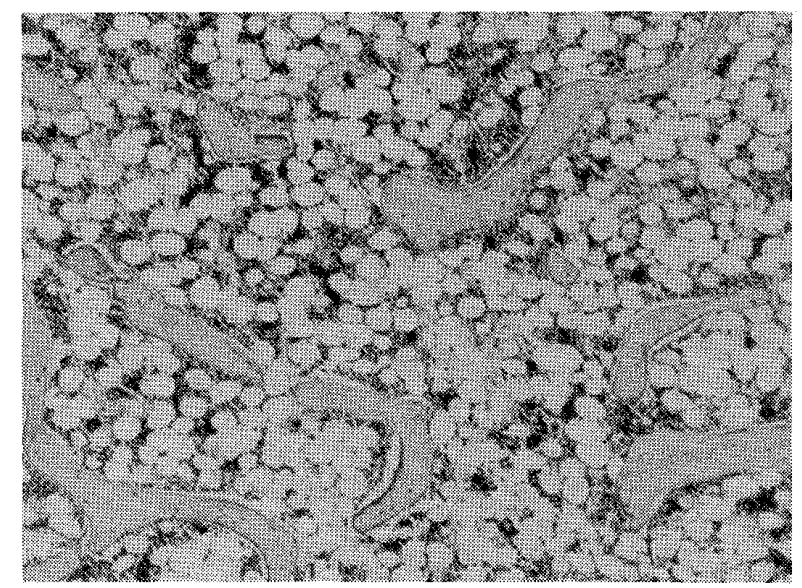

Operated/stimulated group

Fig. 8. Histological pictures of the saggital section of the right femur at the distal metaphysis. 9 months after the beginning of experiment.

H. E. stain retreated with cyanuric chloride during fixation.

has yet been established, although various theories including the estrogen deficiency theory by Albright et al. (1941) have been proposed. Presently it is presumed that osteoporosis may be induced by complicated interactions among congenital, endocrinological (PTH, estrogen, calcitonin, active vitamin $\mathrm{D}$ and adrenal corticosteroid), nutritional (protein and calcium), and mechanical factors. In preparing a model animal of the disease, therefore, investigators have employed a simplified model. So far, immobilization (Saville, 1969), administration of glucocorticoid (Jett et al., 1970), ovariectomy (Aitken et al., 1972; Orimo et al., 1972; Barzel, 1975) and low Ca diet (Bell et al., 1941; Rowland et al., 1967; Salomon \& Volpin, 1972) have been used separately or in combination. In this study, the author employed multiparous mature rats partly because they had a normal ovarian function and partly because the effect of physiological growth could be minimized. Furthermore, from the point of view that clinical osteoporosis is predominant among post-menopausal women, the author employed a model with estrogen deficiency by ovariectomy and disused factors by sciatic neurectomy. 
In this study, PEMF stimulation histologically did not have any influence on physiological aged bone and on cortical bone of experimental osteoporosis. The findings of the MD method and 3-point bending test support this. On the other hand, the o/s group presented larger values for all of $\mathrm{tVsp}, \mathrm{MTT}$, ROV and FrFS than the o/u one. These findings indicate that PEMF stimulation increased bone formation activity and have a preventive effect against bone loss in the cancelloous bone of experimental osteoporosis. Furthermore, the increase of bone formation activity was associated with the increase in bone marrow blood flow. Therefore, it may be reasonable to think that there is a relationship between bone marrow blood flow and bone formation activity.

It has not yet been fully clarified how local bone and marrow blood flows are related to bone turnover. The presence of a close relation between the two is suggested by the facts that vigorous vascular proliferation is associated with a higher bone formation activity in fracture healing, and that a higher bone blood flow was found to be associated with a high rate of bone growth in experiments (Copp \& Shim, 1965; Brookes, 1967; Kane \& Grim, 1969). Using a hydrogen washout technique, Whiteside et al. (1977b) demonstrated that the regional bone blood flow rate was correlated with the osteoblastic activity. Although it is said that PEMF stimulation promotes vascular proliferation in fracture healing, there are few reports describing the direct reaction of blood flow to PEMF stimulation. In their observation at the level of bone micro-vessels using the vital microscopic chamber, Albrektsson (1980) frequently found bone accretion and resorption at regions with relatively wide vessels $(25-60 \mu \mathrm{m})$ and increased bone remodelling along with decreased blood flow by PEMF stimulation at $15 \mathrm{~Hz}$ (Albrektsson et al., 1984). His findings are contradictory to this study. This reason may be due to regional differences in measuring of blood flow, the method of measurement and PEMF stimulation and the non-unitary biological effect of PEMF stimulation.

Table 5 shows a list of authors who investigated the effect of electrical stimulation on experimental osteoporosis. All of the reports document the effectiveness of electrical sti-

Table 5. Reports on the effect of electrical stimulation on experimental osteoporosis

\begin{tabular}{|c|c|c|c|}
\hline Investigator & Animal & Bone loss induced by & Stimulation \\
\hline McElhaney et al. (1968) & rat & plaster cast & $\begin{array}{l}\text { transcutaneous } \\
\text { D. C., A. C. }\end{array}$ \\
\hline Kenner et al. (1975) & rabbit & splinting and casting & $\begin{array}{l}\text { direct (electrode) } \\
5 \mathrm{~Hz} \text { pulsed }\end{array}$ \\
\hline Martin \& Gutman (1978) & rat & plaster cast & $\begin{array}{l}\text { transcutaneous } \\
\text { A. C. }\end{array}$ \\
\hline Bassett et al. (1979) & rat & $\begin{array}{l}\text { muscle removal, neurectomy } \\
\text { and plaster cast. }\end{array}$ & $\begin{array}{l}\text { PEMF } \\
10 \mathrm{~Hz}, 65-72 \mathrm{~Hz}\end{array}$ \\
\hline Cruss et al. (1983) & rat & $\begin{array}{l}\text { muscle removal, neurectomy } \\
\text { and plaster cast }\end{array}$ & $\begin{array}{l}\text { PEMF } \\
65-72 \mathrm{~Hz}\end{array}$ \\
\hline Tadduni et al. (1984) & rat & sciatic neurectomy & $\begin{array}{l}\text { direct (plate) } \\
60 \mathrm{kHz} \text { signal }\end{array}$ \\
\hline
\end{tabular}


mulation in preventing bone loss. Bassett et al. (1979) and Cruess et al. (1983) were the only investigators that employed PEMF stimulation. In their experiments, they noted that PEMF stimulation promoted proteoglycan and collagen and reduced releases of collagenase and prelabelled $\mathrm{Ca}$, thereby preventing bone loss. The experiments presented here were considerably different from those used in the preparing procedure for model rats, the wave form of PEMF, and the methods of observation. The most important difference was that my experiments first demonstrated the preventive effect of PEMF stimulation against bone loss of osteoporosis in association with the increase in bone marrow blood flow.

Nakagawa et al. (1973) noted that they had not experienced any side effects caused by considerably long-term magnetic fields stimulation under 1000 Oe on living bodies. The magnetic fields strength in my experiments was extremely weak. However, because much is also unknown about the biological effect of the magnetic field on living bodies, long-term PEMF stimulation should be carefully used in case of clinical applications.

\section{Conclusions}

1. The biological effect of 6 months systemic PEMF stimulation on the bone was investigated in hindlegs of rats.

2. PEMF stimulation did not affect the physiologically aged bone.

3. PEMF stimulation did not have any influence on bone loss at the cortical bone of experimental osteoporosis prepared by bilateral ovariectomy and unilateral sciatic neurectomy. 4. On the other hand, the cancellous bone was found to have an increase of bone volume and bone formation activity indicating a preventive effect against bone loss.

5. An increase in bone marrow blood flow appeared to be involved in this increase of bone volume and bone formation activity.

\section{Acknowledgment}

The author wishes to express his thanks to Prof. K. Suzuki for his kind instructions, as well as to Prof. H. Sugano for the valuable suggestions in preparation of the magnetic field generator and to Mrs. K. Enomoto for the cooperation in preparation of bone tissue samples.

\section{References}

Aitken, J. M., Armstrong, E. \& Anderson, J. B. (1972): Osteoporosis after oophorectomy in the mature female rat and the effect of oestrogen and/or progestogen replacement therapy in its prevention. J. Endocr., 55: 79-87.

Albrektsson, T. (1980): Repair of bone grafts. Scand. J. Plast. Reconstr. Surg., 14: 1-12.

Albrektsson, T., Buch, F. \& Nannmark, U. (1984): Vascular reactions during electrical and electromagnetical stimulation. In: Bioelectrical Repair and Growth. 4. (Fukuda, E., Inoue, S., Sakou, T. et al., ed.). 
Nishimura Bookshop, Niigata. pp. 116-122.

Albright, F., Smith, P. H. \& Richardson, A. M. (1941): Postmenopausal osteoporosis. J. Am. Med. Assoc., 116: 2465-2474.

Aukland, K., Bower, B. F. \& Berliner, R. W. (1964): Measurement of local blood flow with hydrogen gas. Circ. Res., 14: 164-187.

Barzel, U. S. (1975): Studies in osteoporosis: The long-term effect of oophorectomy and of ammonium chloride ingestion on the bone of mature rats. Endocrinology, 96: 1304-1306.

Bassett, G. A. L. (1962): Gurrent concepts of bone formation. J. Bone Joint Surg., 44-A: 1217-1244.

Bassett, G. A. L. (1984): The development and application of pulsed electromagnetic field (PEMFs) for ununited fractures and arthrodeses. Orthop. Clin. N. Am. 15: 61-87.

Bassett, C. A. L., Caulo, N. \& Kort J. (1981): Congenital "pseudarthroses" of the tibia: treatment electromagnetic fields. Clin. Orthop., 154: 136-149.

Bassett, G. A. L., Mitchell, S. N. \& Gaston, S. R. (1982): Pulsing electromagnetic field treatment in ununited fractures and failed arthrodeses. JAMA, 247: 623-628.

Bassett, G. A. L. \& Pawluk, R. J. (1964): Effects of electric currents on bone in vivo. Nature, 204: 652654.

Bassett, S. L., Tzitzikalakis, G., Pawluk, R. J. et al. (1979): Prevention of disuse osteoporosis in the rat by means of pulsing electromagnetic fields. In: Electrical Properties of Bone and Cartilage: Experimental Effects and Clinical Applications. (Brighton, D. T., Black, J. \& Pollack, S. R., ed.). Grune \& Stratton, New York. pp. 311-331.

Bell, G. H., Cuthbertson, D. P. \& Orr, J. (1941): Strength and size of bone in relation to calcium intake. J. Physiol., 100: 299-317.

Brighton, C. T. \& Heppenstall, R. B. (1971): Oxygen tension in zones of the epiphyseal plate, the metaphysis and diaphysis. An in vitro and in vivo study in rats and rabbits. J. Bone Joint Surg., 53-A: 719.

Brookes, M. (1967): Blood flow rates in compact and cancellous bone, and bone marrow. J. Anat., 101: $533-541$.

Copp, D. H. \& Shim, S. S. (1965): Extraction ratio and bone clearance of $\mathrm{Sr}^{85}$ as a measure of effective bone blood flow. Circulation Res., 16: 461-467.

Cruess, R. L., Kan, K. \& Bassett, A. L. (1983): The effect of pulsing electromagnetic fields on bone metabolism in experimental disuse osteoporosis. Clin. Ortho,, 173: 245-250.

Friedenberg, Z. B., Andrews, E. T., Smolenski, B. I. et al. (1970): Bone reaction to varying amounts of direct current. Surg. Gynecol. Obstet., 131: 894-899.

Friedenberg, Z. B. \& Brighton, C. T. (1966): Bioelectric potential in bone. J. Bone Joint Surg., 48-A: 915-923.

Friedenberg, Z. B., Zemsky, L. M., Pollis, R. P. et al. (1974): The response of non-traumatized bone to direct current. J. Bone Joint Surg., 56-A: 1023-1030.

Heaney, R. P. (1965): A unified concept of osteoporosis. Am. J. Med., 39: 877-880.

Inoue, T., Kushida, K., Miyamoto, S. et al. (1980): Evaluation of degree of bone atrophy using roentgenograms. Bone Metabolism, 13: 187-195. (in Japanese)

Inoue, T., Kushida, K. \& Yamashita, G. (1981): Radiological assessment of bone density using microdensitometer. Bone Metabolism, 14: 91-104. (in Japanese)

Jett, S., Wu, K., Duncan, H. et al. (1970): Adrenal corticosteroid and salicylate actions on human and canine haversian bone formation and resorption. Clin. Orthop., 68: 301-315.

Kane, W. J. \& Grim, E. (1969): Blood flow to canine hind-limb bone, muscle and skin. J. Bone Joint Surg., 51-A: 309-322.

Kenner, G. H., Gabrielson, E. W., Lovell, J. E. et al. (1975): Electrical modification of disuse osteoporosis. Calc. Tiss. Res., 18: 111-117.

Konno, T. \& Takahashi, H. (1983): Preparation of undecalcified bone sections. In: Handbook of Bone 
Morphometry. (Takahashi, H., ed.). Nishimura Bookshop, Niigata. pp. 28-33. (in Japanese with English abstract)

Krauss, W. \& Lechner, F. (1972): Die Heilung von Pseudarthrosen und Spontanfrakturen durch strukturbildende elektrodynamische Potentiale. Munch. Med. Wschr., 114: 1814-1819.

Martin, R. B. \& Gutman, W. (1978): The effect of electric fields on osteoporosis of disuse. Calc. Tiss. Res., 25: 23-27.

McElhaney, J. H., Stalanaker, R. \& Bullard, R. (1968): Electric field and bone loss of disuse. J. Biomech., 1: 47-52.

Nakagawa, K., Hayashi, H., Takamatu, K. et al. (1973): Effects of magnetic field on living organisms. In: Magnetism and living bodies, 1. (Nakagawa, K., ed.). Sun Enterprise, Tokyo. pp. 157-166. (in Japanese)

Orimo, H., Fujita, T. \& Yoshikawa, H. (1972): Increased sensitivity of bone to parathyroid hormone in ovariectomized rats. Endocrinology, 90: 760-763.

Rinsky, L. A., Halpern, A., Schurman, D. B. et al. (1980): Electrical stimulation of experimentally produced avascular necrosis of the femoral head. Orthop. Trans., 5: 131.

Rowland, L. O., Harms, R. H., Wilson, H. R. et al. (1967): Breaking strength of chick bones as an indication of dietary calcium and phosphorus adequancy. Proc. Soc. Exp. Biol. Med., 126: 399-401.

Salomon, C. D. \& Volpin, G. (1972): The effects of calcium-deficient diet on breaking strength and other physical parameters of rat bones. Clin. Orthop., 82: 207-213.

Saville, P. D. (1969): Changes in skeletal mass and fragility with castration in the rats: A model of osteoporosis. J. Am. Geriatr. Soc., 17: 155-166.

Sutcliffe, M. L. \& Goldberg, A. A. J. (1982): The treatment of congenital pseudarthrosis of the tibia with pulsing electromagnetic fields. Clin. Orthop., 166: 45-57.

Tadduni, G. T., Brighton, G. T., Goll, S. R. et al. (1984): Bone formation and bone resorption in the treatment of denervation/disuse osteoporosis in the rat with capacitive coupling. In: Bioelectrical Repair and Growth, 4. (Fukuda, E., Inoue, S., Sakou, T. et al., ed.). Nishimura Bookshop, Niigata. pp. 283286.

Takahashi, H. (1983): Definition and abbreviation of histomorphometric parameters of trabecular and cortical bones. In: Handbook of Bone Morphometry. (Takahashi, H., ed.). Nishimura Bookshop, Niigata. pp. 71-79. (in Japanese with English abstract)

Whiteside, L. A., Lesker, P. A. \& Simmons, D. J. (1977a): Measurement of regional bone and bone marrow blood flow in the rabbit using the hydrogen washout technique. Clin. Orthop., 122: 340-346.

Whiteside, L. A., Simmons, D. J. \& Lesker, P. A. (1977b): Comparison of regional bone blood flow in areas with differing osteoblastic activity in the rabbit tibia. Clin. Orthop., 124: 267-270.

Yasuda, I. (1984): Fundamental problems in the treatment of fracture. In: Piezoelectricity of Bone and Electrical Callus. (Okada, K., ed.). Fuji Printing, Sapporo. pp. 95-128. (in Japanese with English translation)

Yasuda, I., Noguchi, K. \& Iida, H. (1984): Application of electrical callus. In: Piezoelectricity of Bone and Electrical Callus. (Okada, K., ed.). Fuji Printing, Sapporo. pp. 145-155. (in Japanese with English translation)

Yoshiki, S. (1983): A simple histological method for identification of osteoid matrix in decalcified bone. In: Handbook of Bone Morphometry. (Takahashi, H., ed.). Nishimura Bookshop, Niigata. pp. 61-66. (in Japanese with English abstract) 
実験的骨粗鬆症ラットにおけるパルス電磁場長期刺激の影響

三島 真 一

産業医科大学整形外科学教室

要旨：長期にパルス電磁場全身刺激を与えると，骨にいかなる生物学的な影響が及ぶのかを検討 する目的にて実験を行った。実験動物として成熟䧳ラットを用いて，一部に両側卵巣摘出 術と右坐骨神経切除術を施行し，骨粗鬆症のモデルとした。パルス電磁場刺激は, positive amplitude $25 \mathrm{mV}$, negative amplitude $62.5 \mathrm{mV}$, burst width $4.2 \mathrm{~ms}$, pulse width $230 \mu \mathrm{s}, 12$ $\mathrm{Hz}$ の repetitive pulse burst (RPB) 波を使用し，ゲージ内磁場強度は $3-10$ Gauss とした。 6 カ月間の刺激にて，生理的加令骨では，パルス電磁場刺激による影響は骨力学的および 組織学的には認められなかった。骨粗鬆症モデルの皮質骨での骨量低下に対しても，パル 又電磁場刺激による影響は認められなかった。一方海綿骨においては，パルス電磁場刺激 群で bone formation activity が上昇して扔り，骨量低下に対して予防効果が認められた。 この bone formation activity の上昇の発現には，骨䯣内血流量の上昇が関与しているもの と考えられた.

J. UOEH (産業医大誌), 10 ( 1 ): 31-45 (1988) 